\title{
Apoptosis of Human Jurkat $T$ Cells Induced by the Methylene Chloride Extract from the Stems of Zanthoxylum schinifolium is Associated with Intrinsic Mitochondria-Dependent Activation of Caspase Pathway
}

\author{
Do Youn Jun, Mi-Hee Woo', Hae Sun Park, Jun Seok Kim, In Koo Rhee ${ }^{2}$ and Young Ho Kim* \\ School of Life Science and Biotechnology, College of Natural Sciences, Kyungpook National University, Daegu 702-701. \\ ${ }^{1}$ Department of Pharmacy, College of Pharmacy, Daegu Catholic University, Gyeongbuk 712-702. \\ ${ }^{2}$ School of Biological Chemistry, College of Agriculture and Life Science, Kyungpook National University, Daegu 702-701. \\ Received October 29, 2008 / Accepted November 11, 2008
}

\begin{abstract}
To examine antitumor activity of the edible plant Zanthoxylum schinifolium, the cytotoxic effect of various organic solvent extracts of its stems on human acute leukemia Jurkat $\mathrm{T}$ cells was investigated. Among these extracts such as methanol extract (SS-7), methylene chloride extract (SS-8), ethyl acetate extract (SS-9), n-butanol extract (SS-10), and residual fraction (SL-11), SS-8 exhibited the most cytotoxic activity against Jurkat T cells. The methylene chloride extract (SS-8) possessed the apoptogenic activity capable of inducing sub-G $\mathrm{G}_{1}$ peak along with apoptotic DNA fragmentation in Jurkat T cells. Western blot analysis revealed that SS-8 induced apoptosis via mitochondrial cytochrome c release into cytoplasm, subsequent activation of caspase- 9 and caspase- 3 , and cleavage of PARP, which could be blocked by overexpression of Bcl-xL. Jurkat T cell clone I2.1 (FADD ${ }^{-1}$ ) and Jurkat T cell clone 19.2 (caspase- $8^{-/}$) were as sensitive as was the wild-type Jurkat $\mathrm{T}$ cell clone A3 to the cytotoxic effect of SS-8, suggesting no contribution of Fas/FasL system to the SS-8-mediated apoptosis. The GC-MS analysis of SS-8 showed that it was composed of 16 ingredients including 9,12-octadecanoic acid (18.62\%), 2,4-dihydro-5-methyl-4- (1-methylethylidene)-2-(4-nitrophenyl)-3H- pyrazol-3-one (14.97\%), hexadecanoic acid (14.23\%), (z,z)-6,9-pentadecadien-1-ol (13.73\%), 5,6-dimethoxy-2-methyl benzofuran (10.95\%), and 4-methoxy-2-methylcinnamic acid $(5.38 \%)$. These results demonstrate that the methylene chloride extract of the stems of Z. schinifolium can induce apoptotic cell death in Jurkat T cells via intrinsic mitochondria-dependent caspase cascade regulated by Bcl-xL without involvement of the Fas/FasL system.
\end{abstract}

Key words : Zanthoxylum schinifolium, the stem, methylene chloride extract, antitumor activity, apoptosis, mitochondrial cytochrome c release, caspase cascade, GC-MS analysis

\section{Introduction}

Zanthoxylum schinifolium, which belongs to the Rutaceae family, is an aromatic plant whose pericarps and leaves are widely used as a pungent condiment and seasoning and herbal medicine in north-eastern Asian countries such as Korea, and Japan. The fruits, seeds, leaves, and roots of $Z$. schinifolium are known to possess effects as traditional medicine [5,23]. In particular, the dried leaves and the essential oil obtained from pericarps of Z. schinifolium have been used as traditional medicine to treat toothache, muscle pain, sthenia, ascarids, and confusion. Phytochemical investigations on the components of the root bark of $Z$. schinifolium resulted in the isolation of cis-fagaramide [5], coumarin, peroxyterpenyl coumarin $[4,23,24]$, schinifolin,

\footnotetext{
*Corresponding author

Tel : +82-53-950-5378, Fax : +82-53-955-5522

E-mail : ykim@knu.ac.kr
}

$5^{\prime}$-acetoxyschinifolin [6], and others [9,17]. The bioactive ingredients from Z. schinifolium have been reported for their medicinal activities including anti-platelet aggregation $[6,23]$, anti-oxidant activity $[19,20]$, inhibition of the production of monoamine oxidase [9], antimicrobial activity [18], and antitumor activity [7].

As a well-studied chemical component in root bark of $Z$. schinifolium, the coumarin is known to exert cytotoxic effect on cancer cells [7]. However, the cellular mechanism underlying this cytotoxicity still remains obscure. Recently it has been reported that the essential oils from $Z$. schinifolium pericarp, whose major components are sabinene $(15.40 \%)$, citronellal $(15.75 \%)$ and geranyl acetate $(29.8 \%)$, is able to induce apoptosis of human hepatoma HepG2 cells [3]. Recently, we have reported that the methylene chloride extract from the leaves of Z. schinifolium possesses antitumor activity against human acute leukemia Jurkat $\mathrm{T}$ cells, which results from induction of apoptotic cell death, and chemical 
compositions of the methylene chloride extract [14]. More recently, we have investigated the apoptogenic mechanism for 7-[(3,7-dimethyl-2,6-octadienyl)-oxy]-coumarin (auraptene) purified from the leaves of Z. schinifolium, and found that auraptene induces apoptotic cell death of Jurkat $\mathrm{T}$ cells through the endoplasmic reticulum stress-mediated activation of caspase-8, and the subsequent induction of mitochondria-dependent or mitochondria-independent activation of caspase cascade [12]. Until now, however, there is no report on the cytotoxic effect of the stems of Z. schinifolium, and its cytotoxicity toward human tumor cells. In the present study, we describe that the methylene chloride extract of the stems of Z. schinifolium possesses a potent cytotoxic activity toward human acute leukemia Jurkat $\mathrm{T}$ cells, whereas other solvent extracts such as the ethyl acetate extract or the butanol extract are unable to exert cytotoxic effect. Since the methylene chloride extract can induce apoptotic cell death in Jurkat $\mathrm{T}$ cells, the mechanism underlying the induced apoptosis was further investigated in order to evaluate its potency as an antitumor agent.

\section{Materials and Methods}

\section{Reagents, antibodies, and cells}

ECL Western blotting kit was from Amersham (Arlington Heights, IL, USA). Anti-cytochrome c was purchased from Pharmingen (San Diego, CA, USA). Anti-caspase-3, antipoly (ADP-ribose) polymerase (PARP), and anti- $\beta$-actin were purchased from Santa Cruz Biotechnology (Santa Cruz, CA, USA). Anti-caspase-8, anti-caspase-9, and anti-Bid were from Cell Signaling Technology (Beverly, MA, USA). Annexin V-FITC apoptosis kit was from Clontech (Takara Bio Inc., Shiga, Japan). Human acute leukemia Jurkat T cell line E6.1, Jurkat $\mathrm{T}$ cell clone $\mathrm{A} 3$, and FADD-deficient Jurkat $\mathrm{T}$ cell clone I2.1 were purchased from ATCC (Manassas, VA, USA). Stable transfectants of Jurkat T cells (J/Neo and J/Bcl-xL) were supplied from Dr. Dennis Taub (Gerontology Research Center, NIA/NIH, MD, USA). Jurkat T cells were maintained in RPMI 1640 (Life Technologies, Gaithersburg, MD, USA) containing 10\% FBS, $20 \mathrm{mM}$ HEPES (pH 7.0), 5×10 M $\beta$-mercaptoethanol, and $100 \mu \mathrm{g} / \mathrm{ml}$ gentamycin.

Isolation of a cytotoxic component from $Z$.
schinifolium

The leaves of $Z$. schinifolium (Korean name; Sancho) were purchased in the fall of 2003 from Dong-A Garden located in nearby Daegu, South Korea. In order to extract the cytotoxic component in Z. schinifolium, the powder of dried leaves $(3 \mathrm{~kg}$ ) was extracted with $100 \%$ methanol. Sequentially, the methanol extract (SS-7) was evaporated, dissolved in water, and then sequentially extracted with methylene chloride (SS-8), ethyl acetate (SS-9), and n-butanol (SS-10), as described in Fig. 1.

\section{Cytotoxicity assay}

The cytotoxic effect of the individual solvent extracts on Jurkat $\mathrm{T}$ cells was analyzed by 3-(4,5-dimethylthiazol-2-yl)2,5-diphenyltetrazolium bromide (MTT) assay reflecting the cell viability. Briefly, Jurkat T cells $\left(4 \times 10^{4}\right)$ were added to the serial dilution of SS-8 in 96-well plates. At $44 \mathrm{hr}$ after incubation, $50 \mu \mathrm{l}$ of MTT solution $(1.1 \mathrm{mg} / \mathrm{ml})$ was added to each well and incubated for an additional $4 \mathrm{hr}$. After centrifugation, the supernatant was removed from each well and then $150 \mu \mathrm{l}$ of DMSO was added to dissolve the colored formazan crystal produced from MTT. OD values of the solutions were measured at $540 \mathrm{~nm}$ by a plate reader.

\section{Flow cytometric analysis}

The cell cycle progression of Jurkat $\mathrm{T}$ cells following treatment with SS-8 was analyzed by Flow cytometry as described elsewhere [15]. Approximately, $1 \times 10^{6}$ cells were fixed in $66 \%$ ethanol at $4^{\circ} \mathrm{C}$ for $1 \mathrm{hr}$, washed with PBS, and resuspended with $12.5 \mu \mathrm{g}$ of RNase in $250 \mu \mathrm{l}$ of $1.12 \%$ sodium citrate buffer ( $\mathrm{pH}$ 8.45). Incubation was continued at $37^{\circ} \mathrm{C}$ for $30 \mathrm{~min}$ before staining of the cellular DNA with $250 \mu \mathrm{l}$ of propidium iodide $(50 \mu \mathrm{g} / \mathrm{ml})$ for $30 \mathrm{~min}$ at room

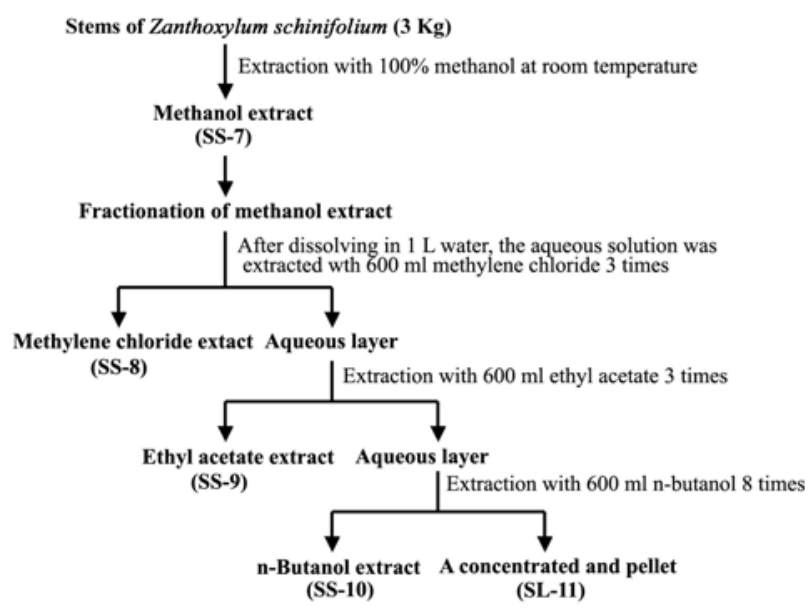

Fig. 1. The procedure for preparation of various organic solvent extracts of the stems of Zanthoxylum schinifolium. 
temperature. The stained cells were analyzed on a flow cytometer for relative DNA content, based on increased red fluorescence.

\section{DNA fragmentation analysis}

Apoptotic DNA fragmentation induced in Jurkat $\mathrm{T}$ cells following SS-8 treatment was determined by Triton X-100 lysis methods using $1.2 \%$ agarose gel electrophoresis as previously described [13].

\section{Preparation of cell lysate and Western blot analysis}

Cell lysates were prepared by using a lysis buffer (137 $\mathrm{mM} \mathrm{NaCl}, 15 \mathrm{mM}$ EGTA, $1 \mathrm{mM}$ sodium orthovanadate, 15 $\mathrm{mM} \mathrm{MgCl} 2,0.1 \%$ Triton X-100, $25 \mathrm{mM}$ MOPS, $2.5 \mu \mathrm{g} / \mathrm{ml}$ proteinase inhibitor E-64, $\mathrm{pH} 7.2$ ) as described previously [12]. An equivalent amount of cell lysate $(20 \mu \mathrm{g})$ was denatured with SDS sample buffer, and subjected to electrophoresis on $4-12 \%$ SDS gradient polyacrylamide gel with MOPS buffer. For detection of caspase-3 activation and mitochondrial cytochrome $c$ release, the protein lysates were electrophoresed on 10\% SDS polyacrylamide gel with 2-(Nmorpholino) ethane-sulfonic acid (MES) buffer. The proteins were electrotransferred to Immobilon-P membranes (Millipore Corporation, Bedford, MA, USA). Detection of each protein was performed using an ECL Western blotting kit, according to the manufacturer's instructions.

Detection of mitochondrial cytochrome c in cytosolic protein extracts

To assess mitochondrial cytochrome c release in Jurkat T cells following SS-8 treatment, cytosolic protein extracts were obtained as described elsewhere [12]. The cytosolic extracts free of mitochondria were analyzed for cytochrome c by Western blotting.

Analysis of the methylene chloride extract by gas chromatography-mass spectrometry (GC-MS)

The GC-MS analysis was conducted with HewlettPackard (HP) 6890 gas chromatography coupled with HP $5903 \mathrm{~N}$ mass spectrometer. A HP-5MS capillary column filled with 5\% Phenyl Methyl Siloxane was connected to the GC instrument. The analytical conditions were as follows: helium carrier gas flow rate, $0.7 \mathrm{ml} / \mathrm{min}$; oven temperature program, $60^{\circ} \mathrm{C}$ (hold for $15 \mathrm{~min}$ ) rising to $280^{\circ} \mathrm{C}$; split ratio, 30:1. The MS instrument was operated in the electron impact (EI) mode and used with ionization energy of $70 \mathrm{eV}$ in an $\mathrm{m} / \mathrm{z}$ range of $50-800$ mass units. The constituents were identified by comparison of their mass spectra with those of internal (computer) library, NIST/EPA/MSDC libraries.

\section{Results and Discussion}

Isoaltion of cytotoxic ingredient in the stems of $Z$. schinifolium by mehtylene chloride extraction

When $3 \mathrm{~kg}$ of the powered dry stems from Z. schinifolium was extracted with $100 \%$ methanol and the methanol extract was then evaporated, $199.2 \mathrm{~g}$ of the solid residue (SS-7) was obtained. To fractionate further the components in the methanol extract, the solid residue was dissolved in water and then sequentially extracted with various organic solvents, such as methylene chloride, ethyl acetate, and n-butanol. The yields of individual solvent extractions were $53.7 \mathrm{~g}$ for methylene chloride extraction (SS-8), $10.6 \mathrm{~g}$ for ethyl acetate extraction (SS-9), $29.6 \mathrm{~g}$ for n-butanol extraction (SS-10), and $50.8 \mathrm{~g}$ for residual water fraction (SS-11), respectively.

To examine whether each extract possesses cytotoxic activity against human acute leukemia Jurakt $\mathrm{T}$ cells, its effect on the cell proliferation was investigated by MTT assay. When the cells were incubated with the individual solvent extracts at concentrations ranging from $100 \mu \mathrm{g} / \mathrm{ml}$ for $48 \mathrm{hr}$, the cell viability appeared to decline in the presence of the methylene chloride extract (SS-8) (Fig. 2). Under these conditions, the cell viability was not significantly altered in the presence of SS-7, SS-9, SS-10, or

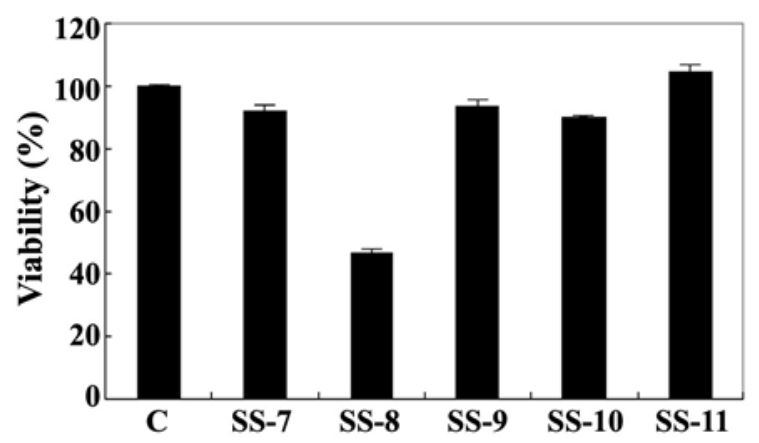

Fig. 2. Cytotoxic effect of the individual organic solvent extracts on human acute leukemia Jurkat $\mathrm{T}$ cells. The cells $\left(4 \times 10^{4}\right.$ cells/well) were incubated with the individual extracts at a concentration of $100 \mu \mathrm{g} / \mathrm{ml}$ in a 96-well plate for $48 \mathrm{hr}$ and the final $4 \mathrm{hr}$ was incubated with MTT to assess the colored formazan crystals produced from MTT as an index of cell viability. 
SS-11. These results demonstrate that the methylene chloride extract of Z. schinifolium stems contains the most cytotoxic activity against human acute leukemia Jurkat $\mathrm{T}$ cells.

Apoptogenic effect of methylene chloride extract (SS-8) on human acute leukemia Jurkat $T$ cells

To understand the mechanism underlying the cytotoxicity of the methylene chloride extract (SS-8), we investigated whether apoptotic cell death was induced in Jurkat $\mathrm{T}$ cells after treatment with SS- 8 . In addition, because the anti-apoptotic role of Bcl-xL was known to center around the prevention of activation of effector caspases including caspase-3 via blocking mitochondrial cytochrome c release into cytosol [2,21,22], we decided to take advantage of this anti-apoptotic role of Bcl-xL to examine if the mitochondrial cytochrome $c$ release and the subsequent activation of caspase cascade were essential steps for SS-8-induced apoptosis. In this context, the cytotoxic effect of SS-8 was compared between Jurkat $\mathrm{T}$ cells transfected with vector (J/Neo) and Jurkat $\mathrm{T}$ cells transfected with Bcl-xL gene (J/Bcl-xL).

When J/Neo cells and J/Bcl-xL cells were treated with SS-8 at various concentrations $(25,50$, or $100 \mu \mathrm{g} / \mathrm{ml})$ for 36 $\mathrm{hr}$, the cell viability of $\mathrm{J} / \mathrm{Neo}$ cells was not influenced at $25 \mu \mathrm{g} / \mathrm{ml}$ but it appeared to decline to $87.9 \%$ at $50 \mu \mathrm{g} / \mathrm{ml}$ and $32.4 \%$ at $100 \mu \mathrm{g} / \mathrm{ml}$ SS-8 (Fig. 3A). The SS-8-mediated decrease in the cell viability was not significant in $\mathrm{J} / \mathrm{Bcl}-\mathrm{xL}$ cells overexpressing Bcl-xL protein. Under the same conditions, the apoptotic DNA fragmentation as well as the ratio of sub- $\mathrm{G}_{1}$ phase representing apoptotic cells, which was induced in J/Neo cells by SS- 8 in a dose-dependent manner, was abrogated in J/Bcl-xL cells (Fig. 3B). Similarly, the flow cytometric analysis confirmed that the apoptotic sub-G $\mathrm{G}_{1}$ phase representing apoptotic cells was detected in J/Neo cells, but not in J/Bcl-xL cells (Fig. 3C). These results indicate that the cytotoxicity of SS-8 toward Jurkat T cells was mainly attributable to induced apoptotic cell death, which is negatively regulated by antiapoptotic protein $\mathrm{Bcl}-\mathrm{xL}$.

Involvement of mitochondrial cytochrome c-mediated
activation of caspase cascade in methylene chloride
extract (SS-8)-induced apoptosis

Many studies have shown that mitochondrial cytochrome c release into cytoplasm is frequently involved in a chemical-induced apoptotic signaling pathway that results
A

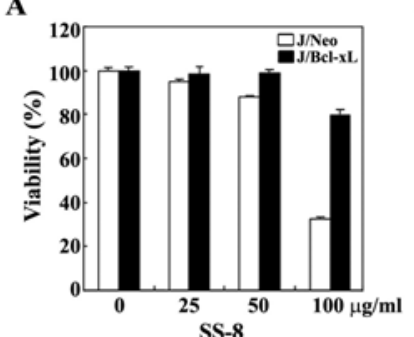

C

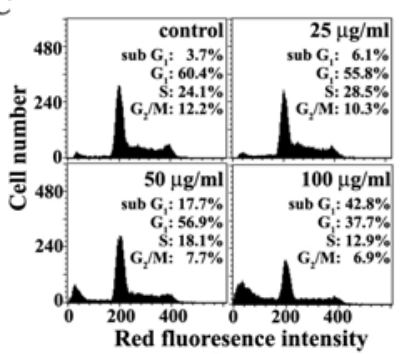

J/Neo
B

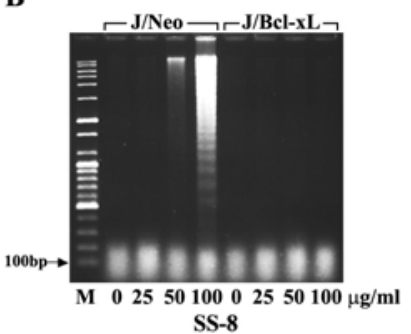

SS-8

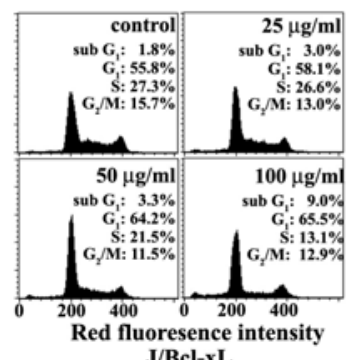

J/Bcl-xL

Fig. 3. Effect of the methylene chloride extract (SS-8) on cell viability (A), apoptotic fragmentation (B), and cell cycle distribution $(C)$ in Jurkat $T$ cells transfected with $\mathrm{Bcl}-\mathrm{xL}$ gene $(\mathrm{J} / \mathrm{Bcl}-\mathrm{xL})$ or vector $(\mathrm{J} / \mathrm{Neo})$. $\mathrm{J} / \mathrm{Bcl}-\mathrm{xL}$ cells or control $(\mathrm{J} / \mathrm{Neo})$ cells were incubated at a density of $4 \times 10^{4} /$ well with various concentrations of SS- 8 in 96-well plates for $48 \mathrm{hr}$ and the final $4 \mathrm{hr}$ were incubated with MTT to assess cell viability. Each value is expressed as mean $\pm S D(n=3)$. ${ }^{*} P<0.05$ as compared with the control. Equivalent cultures were processed to analyze apoptotic DNA fragmentation. To investigate apoptotic change in cell cycle distribution, the cells were fixed with $67 \%$ cold ethanol, stained with propidium iodide, and an equal number of cells $\left(2 \times 10^{4}\right)$ were analyzed by flow cytometry.

in activation of the caspase cascade including capase- 9 and capase-3, and PARP degradation, leading to apoptotic DNA fragmentation $[2,21,22]$. Since both DNA fragmentation and flow cytometric analysis indicate that SS-8-induced apoptosis in Jurkat $\mathrm{T}$ cells could be prevented by ectopic overexpression of $\mathrm{Bcl}-\mathrm{xL}$, it was likely that apoptotic cell death might be associated with mitochondrial cytochrome $\mathrm{c}$ release and resultant activation of the apoptotic caspase cascade.

To examine this prediction, we investigated whether SS-8-induced apoptosis accompanies mitochondrial cytochrome c release into cytosol, and activation of caspase- 9 and -3 , and PARP degradation. As shown in Fig. 4B, $\mathrm{J} / \mathrm{Bcl}-\mathrm{xL}$ cells were able to express significantly enhanced level of Bcl-xL protein as compared to J/Neo cells. Although the level of cytosolic cytochrome c, which was not detected in the continuously growing $\mathrm{J} / \mathrm{Neo}$ cells or 
(A)

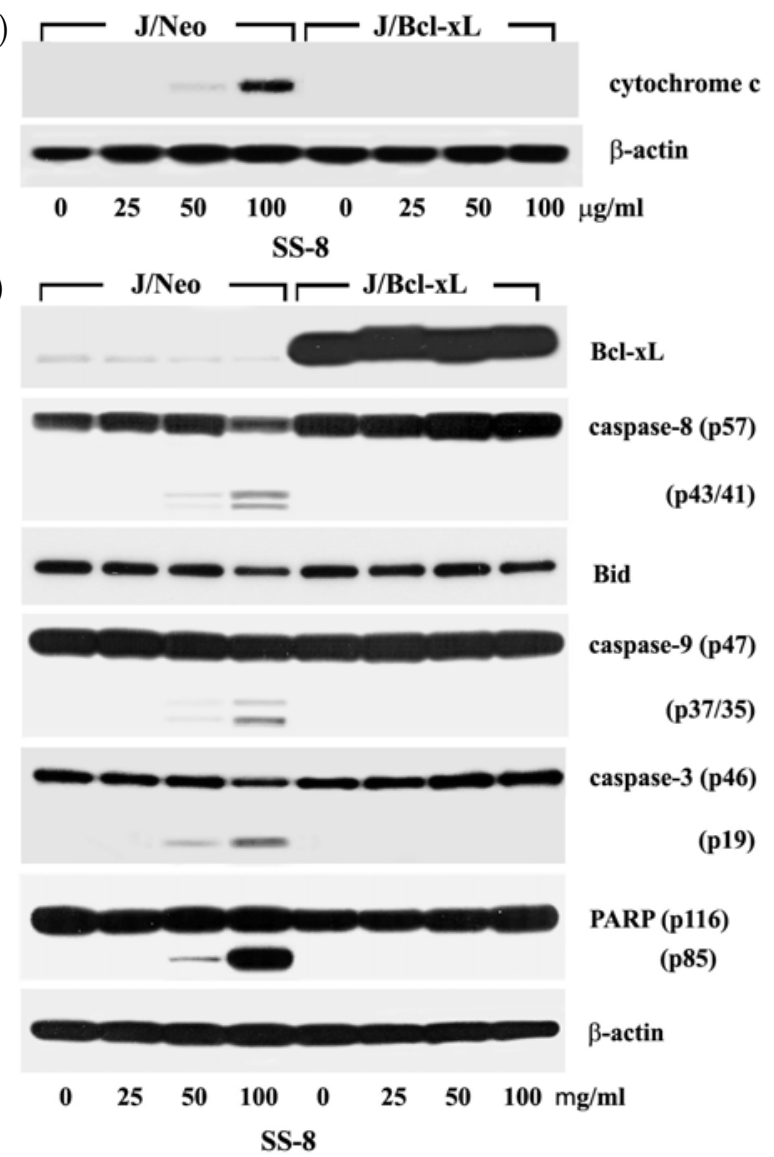

Fig. 4. Western blot analysis of mitochondrial cytochrome c release and $\beta$-actin (A), and caspase- 3 activation, caspase- 9 activation, cleavage of PARP and $\beta$-actin (B) in Jurkat $\mathrm{T}$ cells Jurkat $\mathrm{T}$ cells overexpressing $\mathrm{J} / \mathrm{Bcl}-\mathrm{xL}$ gene $(\mathrm{J} / \mathrm{Bcl}-\mathrm{xL})$ or control cells $(\mathrm{J} / \mathrm{Neo})$ after treatment with the methylene chloride extract (SS-8) for $48 \mathrm{hr}$. The cells $\left(\sim 5 \times 10^{6}\right)$ were incubated at a concentration of $4 \times 10^{5} / \mathrm{ml}$ with indicated concentrations of SS- 8 for 48 $\mathrm{hr}$ and prepared for cell lysates. Equivalent amounts of cell lysates were electrophoresed on 4-12\% SDS gradient polyacrylamide gels and electrotransferred to Immobilon-P membrane. Western analysis was performed as described in Materials and Methods using ECL Western blotting detection system.

J/Neo cells treated with $25 \mu \mathrm{g} / \mathrm{ml} \mathrm{SS}-8$, increased in a dose-dependently in the presence of SS-8 $(50-100 \mu \mathrm{g} / \mathrm{ml})$, it was completely abrogated by the overexpression of $\mathrm{Bcl}-\mathrm{xL}$ (Fig. 4A). In accordance with mitochondrial cytochrome $\mathrm{c}$ release, capase- 9 activation that proceeds through proteolytic degradation of the inactive pro-enzyme $(47 \mathrm{kDa})$ into the active form $(35 \mathrm{kDa})$ was detected. The activation of caspase-3 through proteolytic degradation of a 32-kDa pro-enzyme into a 19-kDa activated form was also detected in a dose-dependent manner in the presence of 50 to $100 \mu \mathrm{g} / \mathrm{ml}$
SS-8. In addition, the caspase-8 activation via the proteolytic degradation of a $57-\mathrm{kDa}$ proenzyme into $41-/ 43-\mathrm{kDa}$ activated form was detected following treatment with SS-8. As a downstream target of active caspase-3 during induction of apoptosis, poly (ADP-ribose) polymerase (PARP) has been reported to be cleaved into two fragments [16]. In J/Neo cells following treatment of SS-8 ranging from 50 to $100 \mu$ $\mathrm{g} / \mathrm{ml}$, the cleavage of PARP was detected along with activation of caspase-3. However, these apoptotic cellular changes were completely abrogated in J/Bcl-xL cells. These results indicate that SS-8-induced apoptosis is associated with mitochondrial cytochrome $\mathrm{c}$ release into cytoplasm, which can be blocked by overexpressed Bcl-xL protein, and resultant activation of caspase cascade including caspase-8, caspase-9, and caspase-3, leading to PARP degradation and apoptotic DNA fragmentation.

To examine further an involvement of Fas/FasL system in SS-8-mediated apoptosis, we compared cytotoxic effect of SS-8 on FADD and caspase-8-positive Jurkat T cells (clone A3) with that on FADD-deficient Jurkat $\mathrm{T}$ cells (clone I2.1) or on caspase-8-deficient Jurkat $\mathrm{T}$ cells (clone 19.2), which were previously refractory to Fas-mediated apoptosis [10]. Irrespective of FADD-deficiency or caspase-8-deficiency, these Jurkat $\mathrm{T}$ cell clones showed similar sensitivity to the cytotoxicity of SS-8 (Fig. 5), excluding the involvement of Fas/FasL system in the SS-8-mediated apoptosis. Since it has

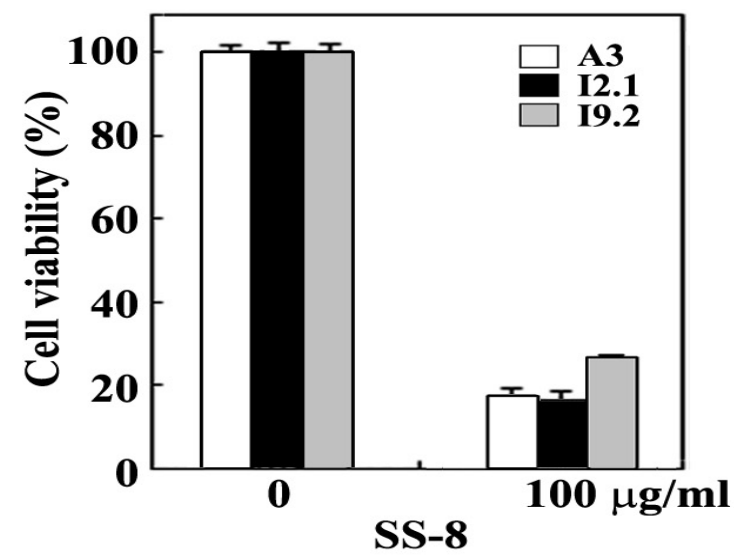

Fig. 5. Cytotoxic effect of the methylene chloride extract (SS-8) on wild-type Jurkat $\mathrm{T}$ cell line A3 (A), FADD-deficient Jurkat $\mathrm{T}$ cell line I2.1 (B), or caspase-8-deficient Jurkat $\mathrm{T}$ cell line I9.2 (C). The cells $\left(4 \times 10^{4}\right.$ cells/well) were incubated with the individual extracts at a concentration of $100 \mu \mathrm{g} / \mathrm{ml}$ in a 96-well plate for $48 \mathrm{hr}$ and the final $4 \mathrm{hr}$ was incubated with MTT to assess the colored formazan crystals produced from MTT as an index of cell viability. 
Table 1. Chemical compositions of the methylene chloride fraction from the stems of Zanthoxylum schnifolium

\begin{tabular}{clrr}
\hline No. & \multicolumn{1}{c}{ Compounds } & RT $(\mathrm{min})^{\mathrm{a}}$ & ${\text { Composition }(\%)^{\mathrm{b}}}^{\mathrm{c}}$ \\
\hline 1 & hexanoic acid & 4.51 & 0.92 \\
2 & 4-methoxy-2-methylcinnamic acid & 20.16 & 5.38 \\
3 & hexadecanoic acid, methyl ester & 23.04 & 2.22 \\
4 & dictamine & 23.39 & 2.72 \\
5 & hexadecanoic acid & 23.63 & 14.23 \\
6 & 2-acetyl-3-ethyl-1,2,5,6-tetrahydro-1-methyl-2+-pyridinecarbonitrile & 23.71 & 4.39 \\
7 & scoparon & 23.91 & 2.53 \\
8 & margaric acid & 24.74 & 1.11 \\
9 & Methyl 8,11-octadecadienoate & 25,74 & 3.15 \\
10 & 9,12,15-octadecatrienoic acid-methylester & 25.83 & 1.23 \\
11 & 9,12-octadecadienoic acid & 26.34 & 18.62 \\
12 & (z,z)-6,9-pentadecadien-1-ol & 26.42 & 13.73 \\
13 & octadecanoic acid & 26.72 & 1.17 \\
14 & 5,6-dimethoxy-2-methyl benzofuran & 27.94 & 10.95 \\
15 & 2,4-dihydro-5-methyl-4-(1-methylethylidene)--2-(4-nitrophenyl)-3H-pyrazol-3-one & 29.75 & 14.97 \\
16 & nonacasane & 36.20 & 2.41 \\
\hline
\end{tabular}

${ }^{a}$ Retention time (in minutes)

${ }^{\mathrm{b}}$ Relative amount (\%)

been reported that caspase- 8 activation can play a role in drug-induced apoptotic signaling pathway either as an upstream event $[1,8,12]$ or as a downstream event of mitochondrial cytochrome c release [11], current data suggest that SS-8-mediated activation of caspase-8 might be down-stream event of mitochondrial cytochrome c release into cytosol or it occurs independently of mitochondria-dependent caspase cascade.

Chemical composition of SS-8 obtained from the stems of Zanthoxylum schnifolium

To examine the ingredients of the methylene chloride extract (SS-8) obtained from the stems of Z. schnifolium, the extract was analyzed by gas chromatography-mass spectrometry (GC-MS). As shown in Table 1, the SS-8 appeared to comprise approximately 16 ingredients, which correspond to $99.73 \%$ of total constituents detected in the extract. As the main components in SS-8 were 9,12-octadecanoic acid (18.62\%), 2,4-dihydro-5-methyl-4-(1-methylethylidene)-2-(4nitrophenyl)-3H-pyrazol-3-one (14.97\%), hexadecanoic acid (14.23\%), (z,z)-6,9-pentadecadien-1-ol (13.73\%), 5,6-dimethoxy-2-methyl benzofuran (10.95\%), 4-methoxy-2-methylcinnamic acid (5.38\%), 2-acetyl-3-ethyl-1,2,5,6-tetrahydro-1mmethyl-2-pyridinecarbonitrile (4.39\%), methyl 8, 11-octadecadienoate $(3.15 \%)$, dictamine $(2.72 \%)$, scoparon $(2.53 \%)$, nonacasane $(2.41 \%)$, and hexadecanoic acid methyl ester $(2.22 \%)$.
This composition of the ingredients is significantly different not only from that of the methylene chloride extract prepared from Z. schinifolium leaves which appeared to induce apoptotic cell death in Jurakt $\mathrm{T}$ cells cells, but also from that of the essential oil prepared from Z. schinifolium pericarps, which could induce apoptosis in HepG2 cells [14]. Although five ingredients such as 9,12-octadecanoic acid, hexadecanoic acid, 4-methoxy-2-methylcinnamic acid , and hexadecanoic acid methyl ester were commonly detected in the methylene chloride extracts of stems and leaves of Z. schinifolium, their composition ratios were markedly different between the stems and leaves.

In conclusion, these results demonstrate that the methylene chloride extract of stems of Zanthoxylum schinifolium possesses an apoptogenic activity causing apoptotic DNA fragmentation of human acute leukemia Jurkat $\mathrm{T}$ cells via mitochondrial cytochrome c release into cytoplasm, and resultant activation of caspase-9 and caspase-3, and cleavage of PARP, which can be negatively regulated by antiapoptotic protein Bcl-xL. Additional GC-MS analysis show that the methylene chloride extract (SS-8) is composed of 16 ingredients including 9,12-octadecanoic acid (18.62\%), 2,4-dihydro-5-methyl-4-(1-methylethylidene)-2-(4-nitrophenyl)-3H-pyrazol-3-one (14.97\%), hexadecanoic acid (14.23\%), (z,z)-6,9-pentadecadien-1-ol (13.73\%), 5,6-dimethoxy2-methyl benzofuran (10.95\%), and 4-methoxy-2-methylcinnamic acid $(5.38 \%)$. These results demonstrate that the cy- 
totoxicity of the methylene chloride extract of Z. schinifolium stems toward human acute leukemia Jurkat $\mathrm{T}$ cells is attributable to apoptosis mediated by mitochondria-dependent caspase cascade regulated by Bcl-xL, and expand our understanding of antitumor activity of Zanthoxylum schinifolium. These findings are useful for evaluating the apoptogenic activity in the edible plant Zanthoxylum schinifolium.

\section{Acknowledgment}

This Study was supported by technology Development Program for Agriculture and Forestry, Ministry of Agriculture and Forestry, Republic of Korea (Grant No. 203008-03-2-HD110).

\section{References}

1. Anto, R. J., A. Mukhopadhyay, K. Denning and B. B. Aggarwal. 2002. Curcumin (diferuloylmethane) induces apoptosis through activation of caspase-8, BID cleavage and cytochrome $c$ release: its suppression by ectopic expression of Bcl-2 and Bcl-xL. Carcinogenesis 23, 143-150.

2. Ashkenazi, A. and V. M. Dixit. 1999. Apoptosis control by death and decoy receptors. Current Opinion in Cell Biology 11, 255-260.

3. Baik, S. Y., K. H. Koh, S. M. Beak, S. H. Pa and J. A. Kim. 2005. The essential oils from Zanthoxylum schinifolium pericarp induce apoptosis of HepG2 human hepatoma cells through increased production of reactive oxygen species. Biological Pharmaceutical Bulletin 28, 802-807.

4. Chang, C. T., S. L. Doong, I. L. Tsai and I. S. Chen. 1997. Coumarins and anti-HBV constituents from Zanthoxylum schinifolium. Phytochemistry 45, 1419-1422.

5. Cheng, M. J., C. H. Yang, W. Y. Lin, I. L. Tsai and I. S. Chen. 2002. Chemical constituents from the leaves of Zanthoxylum schinifolium. Journal of Chinese Chemical Society 49, 125-128.

6. Chen, I. S., Y. C. Lin, I. L. Tsai, C. M. Teng, F. N. Ko, T. Ishikawa and H. Ishii. 1995. Coumarins and anti-platelet aggregation constituents from Zanthoxylum schinifolium. Phytochemistry 39, 1091-1097.

7. Elinos-Baez, C. H., F. Leon and F. Santos. 2005. Effects of coumarin and $7 \mathrm{OH}$-coumarin on Bcl-2 and Bax expression in two human lung cancer lines in vitro. Cell Biology International 29, 703-708.

8. Jimbo, A., E. Fujita, Y. Kouroku, J. Ohnishi, N. Inohara, K. Kuida, K. Sakamaki, S. Yonehara and T. Momoi. 2003. ER stress induces caspase-8 activation, stimulating cytochrome c release and caspase-9 activation. Experimental Cell Research 283, 156-166.

9. Jo, Y. S., D. T. L. Huong, K. H. Bae, M. K. Lee and Y. H.
Kim. 2002. Monoamine oxidase inhibitory coumarin from Zanthoxylum schinifolium. Planta Medica 68, 84-85.

10. Juo, P., M. S. Woo, C. J. Kuo, P. Signorelli, H. P. Biemann, Y. A. Hannun and J. Blenis. 1999. FADD is required for multiple signaling events downstream of the receptor Fas. Cell Growth and Differentiation 10, 797-804.

11. Jun, D. Y., H. S. Park, J. S. Kim, J. S. Kim, W. Park, B. H. Song, H. S. Kim, D. Taub and Y. H. Kim. 2008. 17a -Estradiol arrests cell cycle progression at $\mathrm{G}_{2} / \mathrm{M}$ and induces apoptotic cell death in human acute leukemia Jurkat T cells. Toxicology and Applied Pharmacology 231, 401-412.

12. Jun, D. Y., J. S. Kim, H. S. Park, C. R. Han, Z. Fang, M. H. Woo, I. K. Rhee and Y. H. Kim. 2007. Apoptogenic activity of auraptene of Zanthoxylum schinifolium toward human acute leukemia Jurkat $\mathrm{T}$ cells is associated with ER stress-mediated caspase- 8 activation that stimulates mitochondria-dependent or -independent caspase cascade. Carcinogenesis 28, 1303-1313.

13. Jun, D. Y., S. W. Rue, K. H. Han, D. Taub, Y. S. Lee, Y. S. Bae and Y. H. Kim. 2003. Mechanism underlying cytotoxicity of thialysine, lysine analog, toward human acute leukemia Jurkat $\mathrm{T}$ cells. Biochemical Pharmacology 66, 2291-2300.

14. Kim, J. S., D. Y. Jun, M. -H. Woo, I. -K. Rhee and Y. H. Kim. 2006. Chemical composition and antitumor apoptogenic activity of mehtylene chloride extracts from the leaves of Zanthoxylum schinifolium. Journal of Life Science 16, 546-554.

15. Kim, Y. H., J. J. Proust, M. J. Buchholz, F. J. Chrest and A. A. Nordin. 1992. Expression of the murine homologue of the cell cycle control protein $\mathrm{p} 34^{\text {cdc2 }}$ in T lymphocytes. Journal of Immunology 149, 17-23.

16. Lazebnik, Y. A., S. H. Kaufmann, S. Desnoyers, G. G. Poirer and W. C. Earnshaw. 1994. Cleavage of poly (ADP-ribose) polymerase by a proteinase with properties like ICE. Nature 371, 346-347.

17. Lee, J. W. 1998. Volatile flavor components of Korean sancho fruit and tree (Zanthoxylum schinifolium). Sikpum Yongyang Hakhoechi 7, 493-498.

18. Min, K. H. 1998. Antifungal activity of the extracts of Zanthoxylum schinifolium Sieb. et Zucc. against Dermatophytes. Mokchae Konghak 26, 78-85.

19. Mun, S. I., H. S. Ryu and J. S. Choi. 1997. Inhibition effects of Zanthoxylum schinifolium and its active principle on lipid peroxidation and liver damage in carbon tetrachloride-treated mice. Hanguk Sikpum Yongyang Kwahak Hoechi 26, 943-951.

20. Mun, S. I., H. S. Ryu, H. J. Lee and J. S. Choi. 1994. Further screening for antioxidant activity of vegetable plants and its active principles from Zanthoxylum schinifolium. Hanguk Yongyang Siklyong Hakhoechi 23, 466-471.

21. Nagata, S. 1997. Apoptosis by death factor. Cell 88, 355-365.

22. Sun, X. M., M. MacFarlane, J. Zhuang, B. B. Wolf, D. R. 
Green and G. M. Cohen. 1999. Distinct caspase cascades are initiated in receptor-mediated and chemical-induced apoptosis. Journal of Biological Chemistry 274, 5053-5060.

23. Tsai, I. L., W. Y. Lin, C. M. Teng, T. Ishikawa, S. L. Doong, M. W. Huang, Y. C. Chen and I. S. Chen. 2000.
Coumarins and antiplatlet constituents from the root bark of Zanthoxylum Schinifolium. Planta Medica 66, 618-623.

24. Tsai, I. L., W. Y. Lin, C. T. Chang and I. S. Chen. 1998. Peroxycoumarius from the root bark of Zanthoxylum schihifolium. Journal of Chinese Chemical Society 45, 99-101.

초록 : 인체 급성백혈병 Jurkat $\mathrm{T}$ 세포에 있어서 Zanthoxylum schinifolium 줄기의 methylene chloride 추출물에 의해 유도되는 세포자살기전 규명

전도연 · 우미희 ${ }^{1} \cdot$ 박해선 · 김준석 · 이인구 ${ }^{2} \cdot$ 김영호*

(경북대학교 자연과학대학 생명과학부, ${ }^{1}$ 대구가톨릭대학교 약학대학 약학과, ${ }^{2}$ 경북대학교 농업생명과학대학 응용생물화학부)

식용 및 약용으로 이용되는 산초(Zanthoxylum schinifolium)의 줄기로부터 항암활성 성분을 분리하기 위하여, 산초 줄기를 유기용매로 추출하고 각 추출물의 인체 급성백혈병 암세포에 대한 독성 및 세포자살 유도 활성을 조사하였다. Methanol (SS-7), methylene chloride (SS-8), ethyl acetate (SS-9), n-butanol (SS-10)로 추출한 각 시료와 유기용매 추출 후 잔여분획 (SL-14)의 세포 독성을 인체 급성백혈병 Jurkat T 세포주를 대상으로 조사한 결과, 암세포에 대한 세포독성이 주로 methylene chloride 추출분획인 (SS-8)에서 확인되었다. Methylene chloride 추출물 (SS-8)의 Jurkat T 세포주에 대한 세포독성의 기전은 mitochondria로부터cytochrome c 방출, caspase-9 및 caspase-3 의 활성화, PARP 분해, internucleosomal DNA fragmentation 등의 일련의 생화학적 반응을 수반하며, 항 세포자살 단백질인 $\mathrm{Bcl}-\mathrm{xL}$ 단백질의 과발현에 의해 억제되는 세포자살 기전임을 확인하였다. FADD가 disruption된 Jurkat $\mathrm{T}$ cell clone I2.1 $\left(\mathrm{FADD}^{-1}\right)$ 및 caspase-8가 결핍된 Jurkat T cell clone I9.2 (caspase- $\left.8^{-1}\right)$ 와 함께 the wild-type Jurkat T cell clone A3에 미치는 SS-8의 세포독성작용을 비교 분석한 결과, wild-type Jurkat A3, FADD-deficient Jurkat clone I2.1및 caspase-8-deficient Jurkat clone I9.2 모두는 SS-8의 세포독성에 대해 유사한 정도의 감수성을 나타내었다. 이는 SS-8에 의해 유도되는 apoptosis에 있어서, Fas/FasL system이 관계되지 않음을 시사한다. 한편, SS-8를 GC-MS 분석하여, 9,12-octadecanoic acid (18.62\%), 2,4-dihydro-5-methyl-4-(1-methylethylidene)-2-(4-nitrophenyl)-3H-pyrazol-3-one (14.97\%), hexadecanoic acid (14.23\%), (z,z)-6,9-pentadecadien-1-ol (13.73\%), 5,6-dimethoxy-2-methyl benzofuran $(10.95 \%)$, 그리고 4-methoxy-2-methylcinnamic acid $(5.38 \%)$ 등을 포함한 16 가지의 구성 성분과 그 조성비를 확인하였다. 이상의 연구결과는 산초 줄기에 함유된 항암 활성에 대한 규명과 이해를 증진시킨다. 